\title{
Functional characterization of the first two actinomycete 4-amino-4-deoxychorismate lyase genes
}

Correspondence

Linquan Bai

bailq@sjtu.edu.cn

Received 3 December 2008

Revised 2 April 2009

Accepted 6 April 2009

\author{
Yirong Zhang, Linquan Bai and Zixin Deng
}

Laboratory of Microbial Metabolism and School of Life Sciences and Biotechnology, Shanghai Jiao Tong University, Shanghai 200030, China

\begin{abstract}
In some antibiotic producers, $p$-aminobenzoic acid (PABA) or its immediate precursor, 4-amino4-deoxychorismate (ADC), is involved in primary metabolism and antibiotic biosynthesis. In Streptomyces sp. FR-008, a gene pabC-1 putatively encoding a fold-type IV pyridoxal 5'phosphate (PLP)-dependent enzyme was found within the antibiotic FR-008/candicidin biosynthetic gene cluster, whose inactivation significantly reduced the productivity of antibiotic FR-008 to about $20 \%$ of the wild-type level. Its specific role in PABA formation was further demonstrated by the successful complementation of an Escherichia coli pabC mutant. Moreover, a free-standing gene pabC-2, probably encoding another fold-type IV PLP-dependent enzyme, was cloned from the same strain. Inactivation of $p a b C-2$ reduced antibiotic FR-008 yield to about $57 \%$ of the wild-type level in the mutant, and the complementation of the $E$. coli pabC mutant established its involvement in PABA biosynthesis. Furthermore, a pabC-1/pabC-2 double mutant only retained about $4 \%$ of the wild-type antibiotic FR-008 productivity, clearly indicating that pabC-2 also contributed to biosynthesis of this antibiotic. Surprisingly, apparently retarded growth of the double mutant was observed on minimal medium, which suggested that both pabC1 and pabC-2 are involved in PABA biosynthesis for primary metabolism. Finally, both PabC-1 and PabC-2 were shown to be functional ADC lyases by in vitro enzymic lysis with the release of pyruvate. pabC-1 and pabC-2 appear to represent the first two functional ADC lyase genes identified in actinomycetes. The involvement of these two ADC lyase genes in both cell growth and antibiotic FR-008 biosynthesis sets an example for the interplay between primary and secondary metabolisms in bacteria.
\end{abstract}

\section{INTRODUCTION}

p-Aminobenzoic acid (PABA) is widespread in bacteria, fungi, plants and some parasites, but absent in humans and animals (Basset et al., 2004; Edman et al., 1993; Goncharoff \& Nichols, 1984; Triglia \& Cowman, 1999). In primary metabolism, PABA is an important precursor of folates, including tetrahydrofolate (vitamin $\mathrm{B}_{9}$ ) and its derivatives, which are essential cofactors for one-carbon transfer reactions and thus required for synthesis of methionine, purines, thymidylate, pantothenic acid and $\mathrm{N}$-formylmethionyl-tRNA (Appling, 1991). Moreover, at least in actinomycetes, PABA or its immediate precursor 4-amino-4-deoxychorismate (ADC) is incorporated into many secondary metabolites, such as antibiotic FR-008/candicidin from Streptomyces sp. FR-008/

Abbreviations: aac(3)IV, apramycin-resistance gene; ADC, 4-amino-4deoxychorismate; Apr, apramycin; LDH, lactate dehydrogenase; PABA, p-aminobenzoic acid; PermE*, up-mutated promoter of erythromycinresistance gene; PKS, polyketide synthase; PLP, pyridoxal 5'-phosphate.

Supplementary methods and two supplementary figures are available with the online version of this paper.
Streptomyces griseus IMRU3570 (Gil \& Hopwood, 1983; Hu et al., 1994), aureothin from Streptomyces thioluteus (He \& Hertweck, 2003), neoaureothin from Streptomyces orinoci (Traitcheva et al., 2007), pristinamycin from Streptomyces pristinaespiralis (Blanc et al., 1997) and chloramphenicol from Streptomyces venezuelae (Brown et al., 1996) (Fig. 1a).

PABA is usually biosynthesized through the shikimate pathway in most organisms (Porat et al., 2006). In the wellstudied bacterium Escherichia coli, PABA is synthesized in two steps catalysed by two separate enzymes. In the first step, ADC synthase, a heterodimeric enzyme consisting of PabA and PabB, encoded by $p a b A$ and $p a b B$ respectively, catalyses the conversion of chorismate and glutamine to $\mathrm{ADC}$ and glutamate. In the second reaction, a pyridoxal 5' phosphate (PLP)-containing ADC lyase, encoded by pabC, mediates elimination of pyruvate from ADC and aromatization to give PABA (Green \& Nichols, 1991; Nichols et al., 1989; Ye et al., 1990).

Separate $p a b A$ and $p a b B$ genes have also been identified as being involved in primary metabolism of Streptomyces 


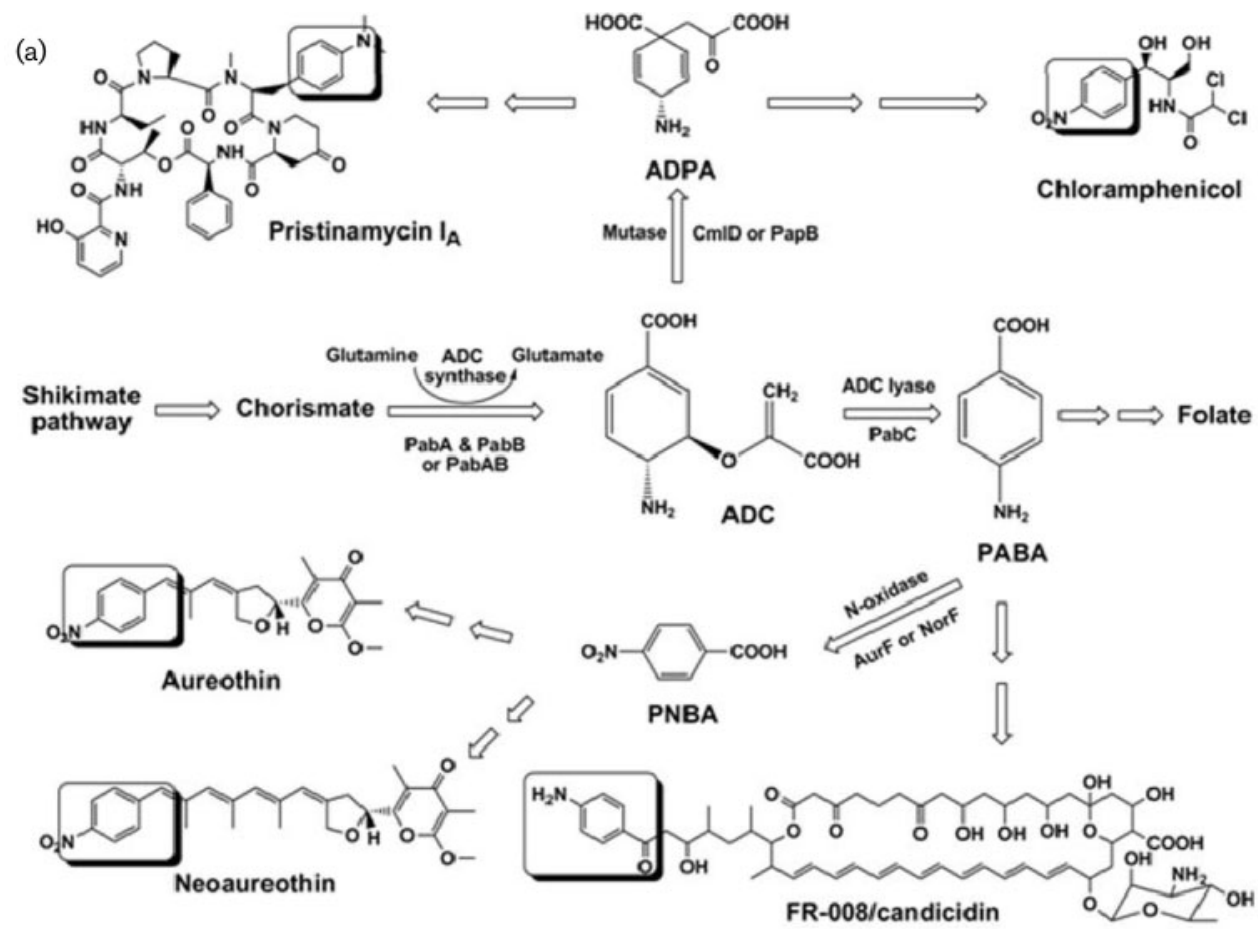

(b)

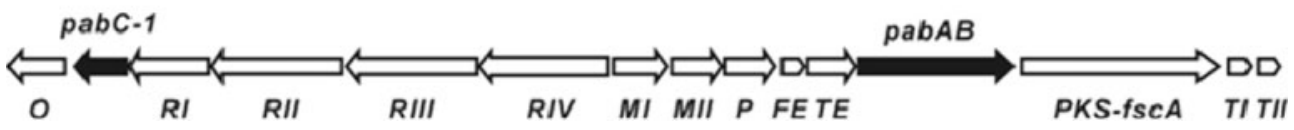

Fig. 1. $P A B A$ metabolism and $A D C$ lyase gene homologue pabC-1 in the antibiotic FR-008 biosynthetic gene cluster. (a) Metabolism of PABA in primary and secondary metabolisms. PABA- or ADC-derived moieties are boxed. ADC, 4-amino-4deoxychorismate; ADPA, 4-amino-4-deoxyprephenic acid; PABA, p-aminobenzoic acid; PNBA, p-nitrobenzoate. (b) Gene organization of the upstream PKS region of the antibiotic FR-008 gene cluster. $p a b A B$ and $p a b C-1$ are highlighted with filled arrows.

lividans (Arhin \& Vining, 1993) and S. venezuelae (Chang et al., 2001) and found in many sequenced Streptomyces genomes (Bentley et al., 2002; Omura et al., 2001). In the biosynthetic pathways for secondary metabolism, however, the pabAB counterparts have been found to be fused in all cases, e.g. those for aureothin (aurG) (He \& Hertweck, 2003), chloramphenicol (cmlB) (He et al., 2001), antibiotic FR-008/candicidin ( $p a b A B)$ (Chen et al., 2003; Gil \& Hopwood, 1983), neoaureothin (norG) (Traitcheva et al., 2007) and pristinamycin (papA) (Blanc et al., 1997). Even though PABA is the immediate precursor for aureothin and neoaureothin biosynthesis, so far only aurG and norG, encoding ADC synthase, have been localized, and the gene encoding ADC lyase has not been identified in these two biosynthetic gene clusters.

Antibiotic FR-008/candicidin is an antifungal heptaene macrolide, whose genetic information and biosynthetic pathway have been demonstrated to be nearly identical in Streptomyces sp. FR-008 and S. griseus IMRU3570. In S. griseus, the fused $p a b A B$, located at one end of the polyketide synthase (PKS) genes, was demonstrated to be essential for antibiotic production because the replacement of pabAB totally abolished antibiotic FR-008 production, which could be restored by feeding with exogenous PABA (Campelo \& Gil, 2002). For antibiotic FR-008 production, a gene encoding an ADC lyase should be required to convert ADC to PABA (Fig. la).

In the work reported here, through in vivo inactivation, complementation and in vitro enzymic catalysis, we first confirmed an ADC lyase gene $p a b C-1$ within the biosynthetic gene cluster to be necessary for efficient antibiotic FR-008 biosynthesis. This was followed by the identification of another ADC lyase gene, $p a b C-2$, which is involved in primary metabolism and in antibiotic FR-008 biosynthesis as well.

\section{METHODS}

Bacterial strains and plasmids. These are listed in Table 1.

General techniques. E. coli strains were cultivated at $37{ }^{\circ} \mathrm{C}$ in Luria-Bertani (LB) medium or on LB agar plates. Streptomyces strains 
Table 1. Strains and plasmids used in this study

\begin{tabular}{|c|c|c|}
\hline Strain or plasmid & Relevant phenotype and/or characteristics & Reference or source \\
\hline \multicolumn{3}{|l|}{ E. coli } \\
\hline DH10B & $\operatorname{rec} A$ & GibcoBRL \\
\hline ET12567/pUZ8002 & recE dam dcm hsdS $\mathrm{Cm}^{\mathrm{r}} \operatorname{Str}^{\mathrm{r}} \operatorname{Tet}^{\mathrm{r}} \mathrm{Km}^{\mathrm{r}}$ & Paget et al. (1999) \\
\hline BW25113 & K12 derivative, $\triangle a r a B A D \triangle r h a B A D$ & Gust et al. (2003) \\
\hline ZYR-9 & BW25113-derived pabC mutant & This study \\
\hline ZYR-9/pJTU927 & ZYR-9 complemented with pJTU927 harbouring full-length FR-008 pabC-1 & This study \\
\hline ZYR-9/pJTU928 & ZYR-9 complemented with pJTU928 harbouring full-length E. coli pabC & This study \\
\hline ZYR-9/pJTU3295 & ZYR-9 complemented with pJTU3295 harbouring full-length FR-008 pabC-2 & This study \\
\hline \multicolumn{3}{|l|}{ Streptomyces sp. } \\
\hline FR-008 & Wild-type producer of antibiotic FR-008 & Hu et al. (1994) \\
\hline $\mathrm{HJ}-5$ & Mutant with the whole antibiotic FR-008 gene cluster deleted & Unpublished \\
\hline ZYR-6 & $\begin{array}{l}\text { FR-008 derivative generated by replacement of a } 437 \mathrm{bp} \text { internal to } p a b C-1 \\
\text { with } 1.4 \mathrm{~kb} \mathrm{aac}(3) I V\end{array}$ & This study \\
\hline ZYR-7 & FR-008 derivative with $p a b C-1 / p a b C-2$ double mutation & This study \\
\hline ZYR-8 & $\begin{array}{l}\text { FR- } 008 \text { derivative generated by deletion of a } 675 \text { bp DNA fragment internal } \\
\text { to } p a b C-2\end{array}$ & This study \\
\hline ZYR-7/pJTU949 & ZYR-7 complemented with pJTU949 harbouring full-length pabC-1 & This study \\
\hline ZYR-7/pJTU3283 & ZYR-7 complemented with pJTU3283 harbouring full-length pabC-2 & This study \\
\hline \multicolumn{3}{|l|}{ Plasmids } \\
\hline pBluescript KS(-) & Phagemid, bla lacZ & Stratagene \\
\hline pMD18 T-vector & pUC18 derivative & TaKaRa \\
\hline pRSET-B & $\mathrm{P}_{\mathrm{T} 7}$ RBS 6xHis Xpress Epitope EK, bla & Invitrogen \\
\hline pET28a & $\mathrm{P}_{\mathrm{T} 7}$ His $\cdot$ Tag/thrombin/T7·Tag, kan & Novogen \\
\hline pJTU1278 & bla lacZ oriT ori(pIJ101) & Unpublished \\
\hline pJTU968 & pRSET-B derivative bla PermE ${ }^{*}$ & Unpublished \\
\hline pРM927 & tsr oriT int attP & Smokvina et al. (1990) \\
\hline pSET152 & $\operatorname{aac}(3) I V \operatorname{ori}(\mathrm{RK} 2) \operatorname{ori}(\mathrm{pUC18}) \operatorname{int}(\phi C 31), \operatorname{attP}(\phi C 31) \operatorname{lac} Z \alpha$ & Bierman et al. (1992) \\
\hline pJTU468 & A $3.0 \mathrm{~kb} \mathrm{KpnI/BamHI}$ fragment carrying pabC-1 cloned in pHGF9053 & This study \\
\hline pJTU469 & $\begin{array}{l}\text { Insertion of a } 1.4 \mathrm{~kb} \text { aac (3)IV gene fragment into the ApaI site sandwiched } \\
\text { between the } 0.8 \mathrm{~kb} \text { and } 1.8 \mathrm{~kb} \text { fragments in ApaI-digested and religated pJTU468 }\end{array}$ & This study \\
\hline pJTU744 & $\begin{array}{l}\text { Cloning of a } 4.0 \mathrm{~kb} B a m \mathrm{HI} / K p n \mathrm{I} \text { fragment from pJTU469 to } \mathrm{pJTU} 1278 \text {, which } \\
\text { contains a linked } 0.8 \mathrm{~kb}(\mathrm{left} \text { arm), } 1.4 \mathrm{~kb} \operatorname{aac}(3) I V \text {, and } 1.8 \mathrm{~kb} \text { (right arm) for } \\
\text { pabC-1 inactivation }\end{array}$ & This study \\
\hline pJTU927 & pET28a carrying the $0.8 \mathrm{~kb}$ FR-008 pabC-1 & This study \\
\hline pJTU928 & pET28a carrying the $0.8 \mathrm{~kb}$ E. coli pabC & This study \\
\hline pJTU949 & pPM927 carrying PermE ${ }^{\star}$ and FR-008 pabC-1 & This study \\
\hline pJTU3283 & pPM927 carrying PermE ${ }^{\star}$ and FR-008 pabC-2 & This study \\
\hline pJTU3286 & pSET152 with the $9.3 \mathrm{~kb}$ EcoRI fragment from cosmid $11 \mathrm{~A} 10$ & This study \\
\hline pJTU3287 & $\begin{array}{l}\text { pSET152 carrying the } 8.7 \mathrm{~kb} E c o \text { RI fragment with } 0.68 \mathrm{~kb} \text { DNA fragment } \\
\text { internal to pabC- } 2 \text { deleted }\end{array}$ & This study \\
\hline pJTU3288 & $\begin{array}{l}\text { Cloning of an } 8.7 \mathrm{~kb} \text { EcoRI fragment from pJTU3287 to pJTU1278, which } \\
\text { contains a linked } 5.6 \mathrm{~kb} \text { (left arm), } 3.1 \mathrm{~kb} \text { (right arm) for pabC-2 inactivation }\end{array}$ & This study \\
\hline pJTU3295 & pET28a carrying the $0.8 \mathrm{~kb}$ FR-008 pabC-2 & This study \\
\hline pJTU3296 & pET28a carrying the $1.4 \mathrm{~kb}$ E. coli pabB & This study \\
\hline
\end{tabular}

were routinely grown at $30{ }^{\circ} \mathrm{C}$ on SFM solid medium (2\% agar, $2 \%$ mannitol, $2 \%$ soybean powder, $\mathrm{pH}$ 7.2) for conjugation between $E$. coli and Streptomyces and solid fermentation, or in TSBY liquid medium (3\% TSB, $1 \%$ yeast extract, $10.3 \%$ sucrose, $\mathrm{pH} 7.2$ ) for mycelial growth. Total DNAs were isolated from Streptomyces strains as described by Kieser et al. (2000). In vivo generation of targeted mutations in Streptomyces was achieved by conjugation between $E$. coli and Streptomyces strains as described previously (Chen et al., 2003) For Streptomyces, apramycin and thiostrepton were used at $30 \mu \mathrm{g} \mathrm{ml}^{-1}$ and $25 \mu \mathrm{g} \mathrm{ml}^{-1}$, respectively, in both SFM agar and liquid media. PABA (Sigma) was used at $5 \mu \mathrm{g} \mathrm{m}{ }^{-1}$ in SFM medium, minimal medium (Kieser et al., 2000) and M9 minimal medium (Sambrook et al., 1989) for feeding experiments. The agar used for minimal medium and M9 minimal medium was purchased from Oxoid. Synthesis of oligonucleotide primers and DNA sequencing of PCR products were performed by Shanghai Sangon and Invitrogen. Extraction of DNA fragments from agarose gel slices was performed with a Gel Recovery kit (Tiangen).

Antibiotic FR-008 detection. Antibiotic FR-008 production by wild-type and mutant strains was determined as follows. Seed culture was prepared in $10.3 \%$ TSBY medium and inoculated with a spore 
suspension. After incubation for $24 \mathrm{~h}$ at $30{ }^{\circ} \mathrm{C}$ and 220 r.p.m., the culture was used to inoculate (at $2 \%, \mathrm{v} / \mathrm{v}) 250 \mathrm{ml}$ flasks containing $50 \mathrm{ml}$ YEME medium minus sucrose. Production of antibiotic FR008 was determined after 5 days. Exogenous PABA (final concentration $5 \mu \mathrm{g} \mathrm{ml}^{-1}$ ) was added to YEME (minus sucrose) cultures at $12 \mathrm{~h}$ after inoculation when necessary. The fermentation broth was extracted with n-butanol. After centrifugation, the n-butanol phase was collected and the $A_{380}$ in butanol was measured in a Perkin-Elmer spectrophotometer (Gil et al., 1980). The blank control experiment was carried out with broth from the fermentation of mutant $\mathrm{HJ}-5$, in which the whole antibiotic FR-008 biosynthetic gene cluster was deleted (unpublished data). Reproducibility of the results was confirmed by at least three independent experiments.

Inactivation of the pabC-1 gene. A $3.0 \mathrm{~kb} \mathrm{KpnI/BamHI} \mathrm{fragment}$ carrying pabC-1 was ligated to KpnI/BamHI-digested pHGF9053 (Minagawa et al., 2007) to give pJTU468. Plasmid pJTU468 was digested with $A p a \mathrm{I}$, blunted and inserted with a $1.40 \mathrm{~kb} a a c(3) I V$ gene fragment from pHGF9827 (Chen et al., 2003) to generate pJTU469. Subsequently, $4.0 \mathrm{~kb}$ of DNA containing the $0.80 \mathrm{~kb}$ fragment (left arm), the $1.40 \mathrm{~kb} \mathrm{aac}(3) I V$ fragment and the $1.80 \mathrm{~kb}$ fragment (right arm) was transferred as a BamHI/KpnI fragment from pJTU469 to BamHI/KpnI-digested pJTU1278. The resultant plasmid pJTU744 was used for targeted replacement of a $437 \mathrm{bp}$ DNA fragment internal to pabC-1 with the $1.40 \mathrm{~kb} a a c(3) I V$ fragment in the wild-type strain FR-008 via conjugation as previously described (Chen et al., 2003). The oligonucleotide primers used for pabC-1 mutant confirmation were PabC-Det-F (5'-GCGGCATGGAGGAAATG-3') and PabC-DetR (5'-CGAACTGGACGGGGAAC-3').

Cloning of pabC-2 from Streptomyces sp. FR-008. To clone the ADC lyase gene homologues from the Streptomyces sp. FR-008 genome, degenerate primers PabB-J1 (5'-GATCGTGGACCTSGTCCGSAACGA-3'; $\mathrm{S}=\mathrm{G} / \mathrm{C})$ and PabC-J8 (5'-GAAGATCCGCATSGCYTTSGCSGT- $3^{\prime}$; $S=\mathrm{G} / \mathrm{C}, \mathrm{Y}=\mathrm{C} / \mathrm{T}$ ) were used to amplify a $1.28 \mathrm{~kb}$ fragment from FR-008 genomic DNA, which was sequenced. Another pair of degenerate primers PabB-J1 and PabC-J9 (5'-GCCGTCGCCCACSGTSAGNCCRTG-3'; $\mathrm{S}=\mathrm{G} / \mathrm{C}, \mathrm{R}=\mathrm{A} / \mathrm{G}, \mathrm{N}=\mathrm{A} / \mathrm{T} / \mathrm{G} / \mathrm{C}$ ) were used to screen the cosmid library of Streptomyces sp. FR-008. A $9.30 \mathrm{~kb}$ EcoRI fragment from a positive cosmid, 11A10, carrying pabC-2 was cloned into the vector pSET152 to generate pJTU3286.

Deletion of pabC-2 in wild-type FR-008 and pabC-1 mutant ZYR-6. Plasmid pJTU3286 was digested with BglII and self-ligated to generate pJTU3287. The shortened $8.70 \mathrm{~kb}$ EcoRI fragment from pJTU3287 was then transferred to the shuttle vector pJTU1278. The resultant plasmid pJTU3288 was used for deletion of a 675 bp DNA fragment internal to $p a b C-2$ in mutant ZYR-6 or wild-type FR-008 via conjugation as previously described (Chen et al., 2003). The pabC-1/ pabC-2 double mutant (ZYR-7) and the pabC-2 single mutant (ZYR8 ) were screened and confirmed by PCR using primers PabB-J1 and PabC-J8.

Complementation of pabC-1/pabC-2 mutant ZYR-7 with cloned pabC-1. The $p a b C-1$ gene was amplified with $\mathrm{KOD}$-plus DNA polymerase using pJTU468 as template and primers PabC1-F (5'-CGGATCCCCATATGATCGAACTGGACG-3'; engineered BamHI and $\overline{N d e I}$ sites underlined) and PabC1-R (5'-TAGAATTCAGAGCGGGGAGCCGGGA-3'; engineered EcoRI site underlined). The PCR amplification was carried out under the following conditions: initial denaturation at $94{ }^{\circ} \mathrm{C}$ for $5 \mathrm{~min}$, then 25 cycles of $45 \mathrm{~s}$ at $94{ }^{\circ} \mathrm{C}$, $45 \mathrm{~s}$ at $60{ }^{\circ} \mathrm{C}$ and $1 \mathrm{~min}$ at $68{ }^{\circ} \mathrm{C}$. A final elongation step was performed at $68{ }^{\circ} \mathrm{C}$ for $5 \mathrm{~min}$. The resultant PCR product was purified and ligated into EcoRV-digested pBluescript KS(-) to generate pJTU903, which was sequenced to validate the inserted DNA sequence. A $0.80 \mathrm{~kb} N d e \mathrm{I} / E c o \mathrm{RI}$ fragment from pJTU903 was ligated to NdeI/EcoRI-digested pJTU968 to give pJTU948. Then the $1.10 \mathrm{~kb} M f e \mathrm{I} / \mathrm{EcoRI}$ fragment, containing the
PermE $E^{*}$ promoter and $p a b C$ - 1 , was cleaved from pJTU948 and ligated into EcoRI-digested pPM927 to give pJTU949. The plasmid was introduced into ZYR-7 via conjugation, and the exconjugants were selected with thiostrepton and confirmed by PCR using primers PabC1$\mathrm{F}$ and PabC1-R.

Complementation of pabC-1/pabC-2 mutant ZYR-7 with cloned pabc-2. The $p a b C-2$ gene was amplified with Taq DNA polymerase using pJTU3286 as template and primers PabC2-F (5'AGGGATCCTCATATGAAGATCTGGCTCG-3'; engineered BamHI and NdeI sites underlined) and PabC2-R (5'-GTTTCTGACGAATTCAGGGGTCGATGT-3'; engineered EcoRI site underlined). The PCR amplification was carried out under the following conditions: initial denaturation at $94{ }^{\circ} \mathrm{C}$ for $5 \mathrm{~min}$, then 25 cycles of $45 \mathrm{~s}$ at $94{ }^{\circ} \mathrm{C}, 45 \mathrm{~s}$ at $60{ }^{\circ} \mathrm{C}$ and $1 \mathrm{~min}$ at $72{ }^{\circ} \mathrm{C}$. A final elongation step was performed at $72{ }^{\circ} \mathrm{C}$ for $5 \mathrm{~min}$. The resultant PCR product was purified and ligated into pMD18 T-vector (TaKaRa) to generate pJTU3293, which was sequenced to validate the inserted DNA sequence. A $0.80 \mathrm{~kb} \mathrm{NdeI/EcoRI} \mathrm{fragment} \mathrm{from} \mathrm{pJTU3293} \mathrm{was} \mathrm{ligated}$ to NdeI/EcoRI-digested pJTU968 to give pJTU3282. Then the $1.10 \mathrm{~kb}$ $M f e I / E c o R I ~ f r a g m e n t$, containing the PermE $E^{*}$ promoter and pabC-2, was cleaved from pJTU3282 and ligated into EcoRI-digested pPM927 to give pJTU3283. The plasmid was introduced into ZYR-7 via conjugation, and the exconjugants were selected with thiostrepton and confirmed by PCR using primers PabC2-F and PabC2-R.

Complementation of $E$. coli pabC mutant ZYR-9 with FR-008 pabC-1or pabC-2. The pabC gene of E. coli BW25113 was replaced with $\operatorname{aac}(3) I V$ using the $\lambda$-Red-mediated recombination system (for details, see the supplementary material available with the online version of this paper). The $p a b C-1$ and $p a b C-2$ genes were subsequently subcloned using the NdeI and EcoRI restriction sites into pET28a (Novagen) to generate pJTU927 and pJTU3295, respectively. The mutant ZYR-9 was transformed with pJTU927 or pJTU3295, and the transformants were cultivated on M9 minimal medium (plus or minus PABA) for $24 \mathrm{~h}$ at $37{ }^{\circ} \mathrm{C}$. The derivatives of mutant ZYR-9 transformed with pJTU928 (see supplementary material) or the vector pET28a were used as the controls.

Overexpression of PabB (E. coli), PabC (E. coli), PabC-1 and PabC-2. Overexpression of PabB (E. coli) in E. coli BL21(DE3)/pLysE harbouring pJTU3296 (see supplementary material) was induced by addition of $0.5 \mathrm{mM}$ IPTG to LB medium at $\mathrm{OD}_{600} 0.7$. Incubation was continued for $12 \mathrm{~h}$ at $25^{\circ} \mathrm{C}$. The cell pellet was harvested, resuspended in lysis buffer $\left(50 \mathrm{mM} \mathrm{NaH} \mathrm{PO}_{4}, 300 \mathrm{mM} \mathrm{NaCl}\right.$, $10 \mathrm{mM}$ imidazole, $\mathrm{pH} \mathrm{8.0)}$, and disrupted by sonication. After centrifugation, the supernatant was passed through a nickel column and bound protein was eluted with elution buffer $\left(50 \mathrm{mM} \mathrm{NaH}_{2} \mathrm{PO}_{4}\right.$, $300 \mathrm{mM} \mathrm{NaCl}, 250 \mathrm{mM}$ imidazole, $\mathrm{pH}$ 8.0). The final protein sample was dialysed against dialysis buffer $\left(20 \mathrm{mM} \mathrm{KH}_{2} \mathrm{PO}_{4}, \mathrm{pH} 7.4,50 \mathrm{mM}\right.$ $\mathrm{KCl})$. Protein concentration was determined by Bradford assay (Sangon).

LB medium was used to culture E. coli BL21(DE3)/pLysE harbouring pJTU928 (for PabC), pJTU927 (for PabC-1) or pJTU3295 (for PabC2) at $37{ }^{\circ} \mathrm{C}$. Overexpression of target proteins was induced by addition of $0.5 \mathrm{mM}$ IPTG at $\mathrm{OD}_{600} 0.6$. Incubation was continued for $16 \mathrm{~h}$ at $22{ }^{\circ} \mathrm{C}$. The cell pellet was resuspended in lysis buffer $(50 \mathrm{mM}$ $\mathrm{NaH}_{2} \mathrm{PO}_{4}, 300 \mathrm{mM} \mathrm{NaCl}, 10 \mathrm{mM}$ imidazole, $20 \mu \mathrm{M}$ PLP, pH 8.0) and disrupted by sonication. After centrifugation, the supernatant was passed through a nickel column, and the bound protein was eluted with elution buffer $\left(50 \mathrm{mM} \mathrm{NaH} \mathrm{PO}_{4}, 300 \mathrm{mM} \mathrm{NaCl}, 250 \mathrm{mM}\right.$ imidazole, $20 \mu \mathrm{M}$ PLP, pH 8.0). The enzyme was monitored by its yellow colour.

Enzymic analysis of PabC (E. coli), PabC-1 and PabC-2. Chorismate (barium salt), NADH and lactate dehydrogenase (LDH) 
were purchased from Sigma. $\mathrm{Ba}^{2+}$ in the commercial chorismate was removed by addition of a slight excess of $\mathrm{Na}_{2} \mathrm{SO}_{4}$ before use. Enzymic catalysis was performed as previously described (He et al., 2004). The pyruvate formation in the ADC lysis reaction was detected by a coupled LDH reaction, which oxidizes NADH to NAD. The consumption of NADH was continuously monitored at $340 \mathrm{~nm}$ in a Perkin-Elmer spectrophotometer using the time-drive programme. The $1 \mathrm{ml} \mathrm{NH}_{4}^{+}$-dependent assay contained $100 \mathrm{mM}$ Bicine ( $\mathrm{pH} 8.5$ ), $100 \mathrm{mM}\left(\mathrm{NH}_{4}\right)_{2} \mathrm{SO}_{4}, 5 \mathrm{mM} \mathrm{MgCl}, 20 \mu \mathrm{M}$ PLP, $5 \mathrm{mM}$ chorismate (sodium salt), $200 \mu \mathrm{M} \mathrm{NADH}, 5$ units LDH ml ${ }^{-1}, 16 \mu \mathrm{M} \mathrm{PabB}$, and 11.3 $\mu \mathrm{M}$ PabC-1 or $22.8 \mu \mathrm{M}$ PabC-2 or $38.2 \mu \mathrm{M}$ E. coli PabC. All assays were performed at $37^{\circ} \mathrm{C}$. The negative controls were carried out with boiled PabB or PabC, or without chorismate.

\section{RESULTS}

\section{The pabc-1 gene, encoding a fold-type IV PLP- dependent enzyme, affects antibiotic FR-008 biosynthesis}

Beyond the four putative regulatory genes (Fig. 1b) the gene pabC-1 is located, encoding a fold-type IV PLPdependent enzyme; these enzymes include D-amino acid aminotransferases, branched-chain amino acid aminotransferases and ADC lyases. Since the gene $p a b A B$ was previously shown to encode the ADC synthase involved in antibiotic FR-008/candicidin biosynthesis (Campelo \& Gil, 2002), pabC-1 was assumed to be an ADC lyase gene for providing the PABA starter unit. PabC-1 showed $27 \%$ and $33.1 \%$ similarities with PabCs from E. coli and Bacillus subtilis, respectively. In silico analysis of PabC-1 identified the conserved residues believed to be essential for catalysis (Lys130) and pyridoxal 5'-phosphate (PLP) binding (Arg44, Lys130, Glu163) for ADC lyase (see supplementary Fig. S2).

The possible involvement of $p a b C-1$ in antibiotic FR-008 biosynthesis was examined through gene replacement. In the pJTU1278-derived plasmid pJTU744, the apramycinresistance gene $\operatorname{aac}(3) I V$ was inserted between the $0.80 \mathrm{~kb}$ left-flanking and the $1.80 \mathrm{~kb}$ right-flanking sequence of the $437 \mathrm{bp}$ DNA fragment to be replaced (Fig. 2a). Two thiostrepton-sensitive, apramycin-resistant (Thio ${ }^{\mathrm{S}} \mathrm{Apr}^{\mathrm{R}}$ ) recombinant mutants (ZYR-6-a and ZYR-6-b) were obtained. Total DNAs from these two strains and from the wild-type were used as templates for PCR analysis with primers PabC-Det-F and PabC-Det-R. The wild-type gave a $0.85 \mathrm{~kb}$ PCR product, whereas the mutants gave a $1.80 \mathrm{~kb}$ PCR product (Fig. 2b), which confirmed that a $437 \mathrm{bp}$ DNA fragment internal to pabC-1 had been replaced by the $1.40 \mathrm{~kb}$ aac(3)IV cassette (Fig. 2a). Spectrophotometric quantification of the fermentation extract of the mutant ZYR-6 clearly showed that antibiotic FR-008 productivity was severely reduced, to approximately $20 \%$ of the wildtype level. When exogenous PABA was added to the fermentation medium for ZYR-6, the antibiotic FR-008 production was restored to around $47 \%$ of the wild-type level (Fig. 2c). This result indicated that $p a b C-1$ is involved in the biosynthesis of antibiotic FR-008.

\section{Identification of a second gene (pabc-2) encoding a fold-type IV PLP-dependent enzyme from Streptomyces sp. FR-008}

The mutant with $p a b C-1$ inactivated still retained about $20 \%$ of the wild-type level of antibiotic FR-008 production, suggesting the involvement of other ADC lyase gene(s) in the genome of Streptomyces sp. FR-008. Considering that the ADC lyase genes involved in folate biosynthesis could be conserved in Streptomyces, we searched for PabC-1 homologues in the genomes of $S$. coelicolor A3(2) (Bentley et al., 2002), S. avermitilis (Omura et al., 2001) and S. griseus (Ohnishi et al., 2008). The best hits were SCO1546 (identity $25.6 \%$, similarity $34.4 \%$; putative type IV aminotransferase) (Bentley et al., 2002), SAV6804 (identity $23.3 \%$, similarity $33.3 \%$; putative Dalanine aminotransferase) (Omura et al., 2001) and SGR5991 (identity $21.2 \%$, similarity $29.7 \%$; putative aminotransferase) (Ohnishi et al., 2008) from S. coelicolor $\mathrm{A} 3(2), S$. avermitilis, and $S$. griseus, respectively. Interestingly, each hit for a $p a b C-1$ homologue lies downstream of a putative anthranilate synthase, probably forming an operon in each strain. The information was used for the design of a pair of degenerate primers (PabB$\mathrm{J1}$, located in $p a b B$ homologues, and PabC-J8, residing in $p a b C$ homologues) for the cloning of a putative region spanning the putative $p a b B-p a b C$ by PCR amplification using total DNA of the wild-type Streptomyces sp. FR-008 as template.

Indeed, a $1.28 \mathrm{~kb}$ PCR product was obtained and sequenced, which contained a $5^{\prime} 0.49 \mathrm{~kb}$ DNA with significant similarity to $S C O 1547$ and a $3^{\prime} 0.78 \mathrm{~kb}$ similar to SCO1546 as expected. A pair of more efficient degenerate primers, PabB-J1 and PabC-J9, was then used to screen the cosmid library of Streptomyces sp. FR-008. Four positive cosmids (5E2, 11A10, 15F4 and 31D2) were obtained. Subcloning and sequencing of a larger $2.0 \mathrm{~kb}$ fragment containing the previous $1.28 \mathrm{~kb}$ sequence identified a complete gene encoding a fold-type IV PLPdependent enzyme, with a downstream incomplete open reading frame similar to SCO1545 (GenBank accession number FJ496753). This complete gene was named pabC-2; its predicted encoded protein has only a weak homology (identity $25.6 \%$, similarity $35.9 \%$ ) with PabC-1, but contains the three conserved residues Arg50, Lys141, and Glu174 putatively essential for ADC lyase activity (see Supplementary Fig. S2).

\section{pabC-2 contributes to antibiotic FR-008 biosynthesis}

In order to identify the possible role of pabC-2, a $9.30 \mathrm{~kb}$ EcoRI fragment carrying this gene from one of the cosmids, $11 \mathrm{~A} 10$, was cloned. For the generation of a mutant with a 675 bp DNA deletion internal to pabC-2, the pJTU1278derived plasmid pJTU3288, with $5.60 \mathrm{~kb}$ left-flanking and $3.10 \mathrm{~kb}$ right-flanking sequence of the $675 \mathrm{bp}$ DNA to be deleted, was introduced into the wild-type strain by 

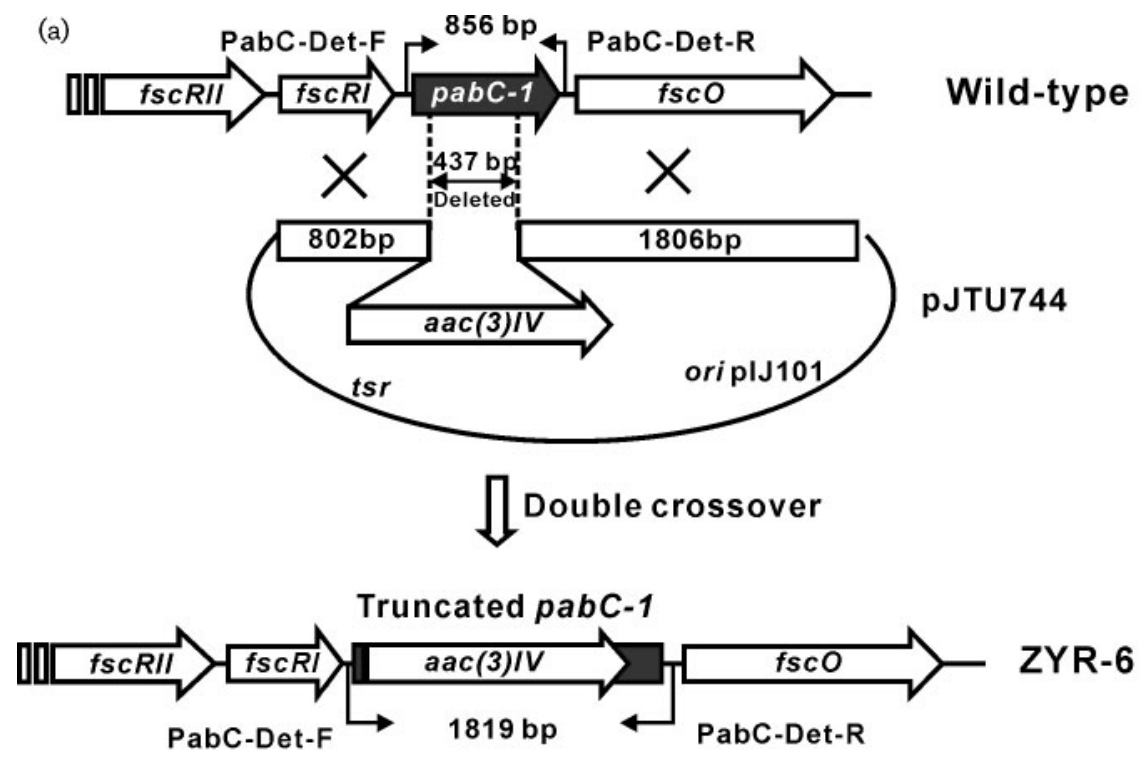

(b)

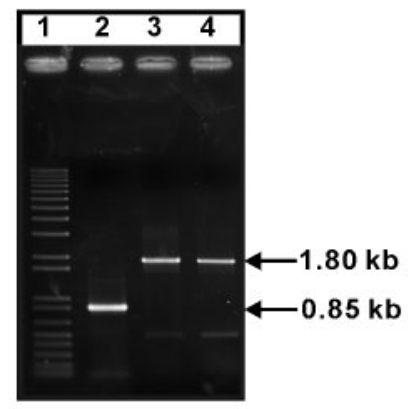

(c)

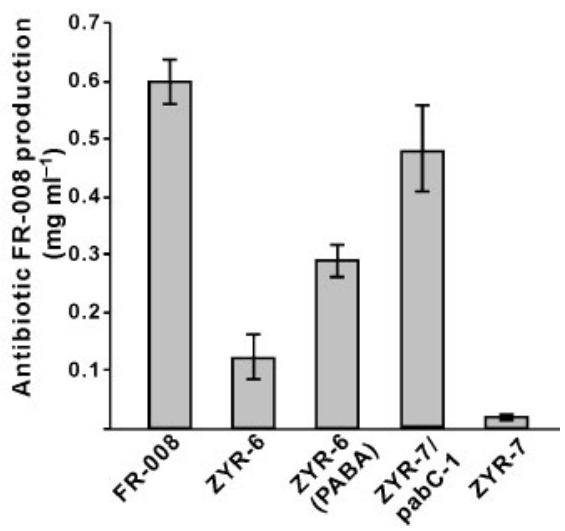

Fig. 2. Inactivation of $p a b C-1$. (a) Schematic representation of pabC-1 inactivation. (b) PCR analysis of wild-type and mutant ZYR-6 using PabC-Det-F and PabC-Det-R as primers. Lanes: 1, 1 kb ladder; 2, wild-type; 3, ZYR-6-a; 4, ZYR-6-b. (c) Spectrophotometric quantification of antibiotic FR-008 production in wild-type, ZYR-6, ZYR-6 fed with exogenous PABA, pabC-1/pabC-2 double mutant ZYR-7 complemented with cloned pabC-1, and ZYR-7. Each column represents the mean value obtained from at least three independent experiments and the error bars indicate the standard deviation.

conjugation (Fig. 3a). Two suitable mutants (ZYR-8-a and ZYR-8-b) were obtained and confirmed by PCR using PabB-J1 and PabC-J8 as primers to carry a $0.6 \mathrm{~kb}$ PCR product, while the PCR fragment derived from the wildtype FR-008 was apparently about $1.30 \mathrm{~kb}$ (675 bp larger) (Fig. 3b). Spectrophotometric quantification of the fermentation extract indicated that the mutant strain (ZYR-8) produced only about $57 \%$ of the wild-type amount of antibiotic FR-008 (Fig. 3c).

\section{pabC-1/pabC-2 double mutation severely reduces antibiotic FR-008 production and renders the mutant PABA-auxotrophic}

To further validate the contribution of $p a b C-2$ to antibiotic FR-008 production in ZYR-6, a pabC-1/pabC-2 double mutant (ZYR-7) was constructed by additional inactivation of pabC-2 in pabC-1 mutant ZYR-6. The genotype of ZYR7 was confirmed by PCR amplification as previously described for the confirmation of pabC-2 mutant ZYR-8 (Fig. 3b). As expected, spectrophotometric quantification indicated that this double mutant produced antibiotic FR008 at about $4 \%$ of the wild-type level, confirming that pabC-1 and pabC-2 are involved in antibiotic FR-008 biosynthesis (Fig. 3c).

When restreaked to minimal medium, the $p a b C-1 / p a b C-2$ double mutant ZYR-7 surprisingly showed very limited growth (Fig. 4). When exogenous PABA was added to minimal medium, the growth of the double mutant was restored (Fig. 4), and the antibiotic production recovered to $47 \%$ of the wild-type level (Fig. 3c). Therefore both pabC-1 and pabC-2 appear to be involved in PABA biosynthesis in primary metabolism. 
(a)
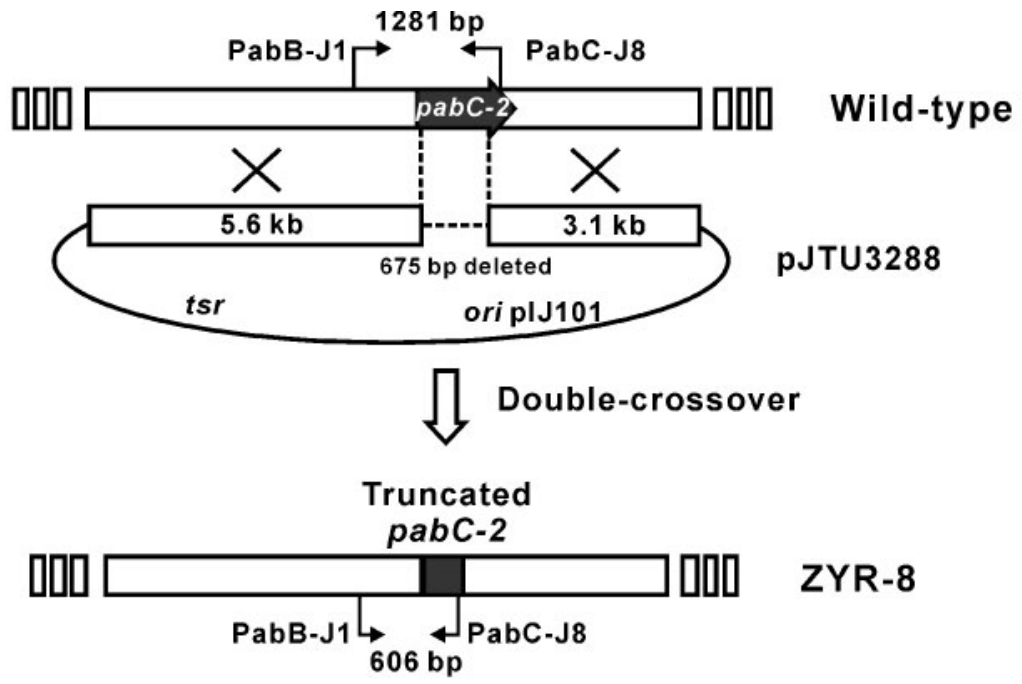

(b)

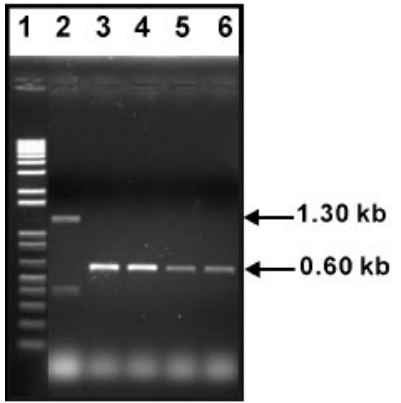

(c)

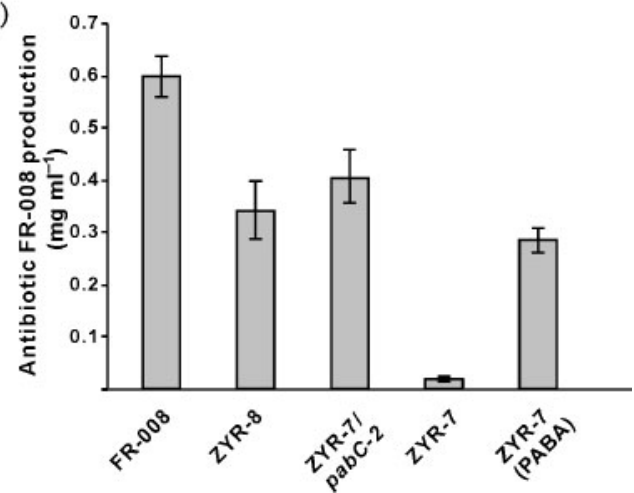

Fig. 3. Inactivation of pabC-2. (a) Schematic representation of pabC-2 inactivation. (b) PCR analysis of wild-type, pabC-2 mutant ZYR-8, and pabC-1/pab-C2 double mutant ZYR-7 with primers PabB-J1 and PabC-J8. Lanes: 1, 1 kb ladder; 2, wildtype; 3, ZYR-7-a; 4, ZYR-7-b; 5, ZYR-8-a; 6, ZYR-8-b. (c) Spectrophotometric quantification of antibiotic FR-008 production in wild-type, pabC-2 mutant ZYR-8, pabC-1/pab-C2 double mutant ZYR-7 complemented with cloned pabC-2, ZYR-7, and ZYR-7 fed with exogenous PABA. Each column represents the mean value obtained from at least three independent experiments and the error bars indicate the standard deviation.

\section{Recovery of antibiotic FR-008 productivity in pabC-1/pabC-2 mutant ZYR-7 with cloned pabc-1 or pabC-2}

To further confirm that $p a b C-1$ and $p a b C-2$ are involved in antibiotic FR-008 biosynthesis, plasmids pJTU949 and pJTU3283, harbouring $p a b C-1$ and $p a b C-2$ respectively, were introduced into the double mutant ZYR-7 by conjugation. Under the control of the strong constitutive PermE $^{\star}$ promoter, pabC-1 and pabC-2 complemented antibiotic FR-008 production in strain ZYR-7 to about $78 \%$ (Fig. 2c) and $67 \%$ (Fig. 3c), respectively, of the wildtype level.

\section{Successful complementation of an E. coli pabC mutant with cloned pabC-1 or pabC-2}

The evidence that PabC-1 and PabC-2 were involved in the biosynthesis of PABA, the starter unit of antibiotic
FR-008, came from the complementation of an E. coli $p a b C$ mutant with cloned pabC-1 and pabC-2, respectively. For this purpose, an E. coli BW25113 pabC mutant, ZYR-9, was constructed using the $\lambda$-Red-mediated recombination system (Gust et al., 2003) (see supplementary material and Fig. S1). The genes $p a b C-1$ and pabC-2 were cloned into $E$. coli expression vector pET28a, and the resultant constructs pJTU927 and pJTU928 were used to transform the mutant ZYR-9 separately. Expression of FR-008 PabC-1 or PabC-2 restored the ability of the mutant ZYR-9 to grow well without PABA supplementation in M9 minimal medium (Fig. 5). The mutant transformed with pJTU928 (harbouring E. coli $p a b C$; see supplementary material) was used as the positive control. In the absence of $\mathrm{PABA}$, the slight growth of mutant ZYR-9 and its derivative containing vector pET28a was due to a low rate of spontaneous PABA formation from ADC (Fig. 5). 


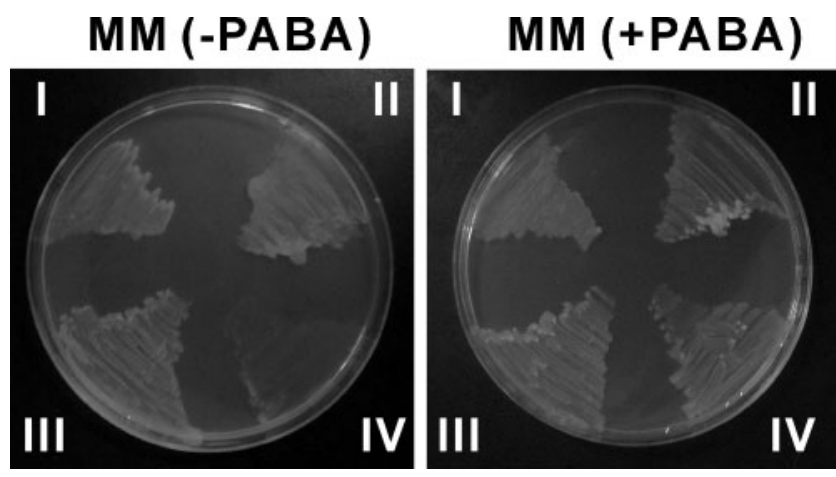

Fig. 4. Growth of wild-type (I), pabC-2 mutant ZYR-8 (II), pabC-1 mutant ZYR-6 (III) and pabC-1/pab-C2 double mutant ZYR-7 (IV) on minimal medium with or without PABA supplementation.

\section{Enzyme assays confirm that PabC-1 and PabC-2 are functional ADC lyases}

In order to examine the biochemical functions of the PabC- 1 and PabC-2 proteins, the individual recombinant proteins were overexpressed and assayed in vitro for ADC lyase activity. For comparison, E. coli $\mathrm{PabC}$ was also overexpressed and purified. The recombinant E. coli $\mathrm{PabB}$ and $\mathrm{NH}_{4}^{+}$were used to convert chorismate to ADC, which is the substrate of ADC lyase. Subsequent cleavage of ADC by ADC lyase will release pyruvate, which is then reduced to lactate by $\mathrm{LDH}$ with coupled oxidization of NADH to NAD (He et al., 2004; Ye et al., 1990). The decrease of $\mathrm{NADH}$ concentration was monitored continuously at $340 \mathrm{~nm}$ (Fig. 6). The ADC lyase activity of E. coli PabC, as the positive control, was tested first. The $A_{340}$ decreased dramatically within $4 \mathrm{~min}$ in the presence of chorismate, PabB and E. coli PabC. When E. coli PabC was omitted, the

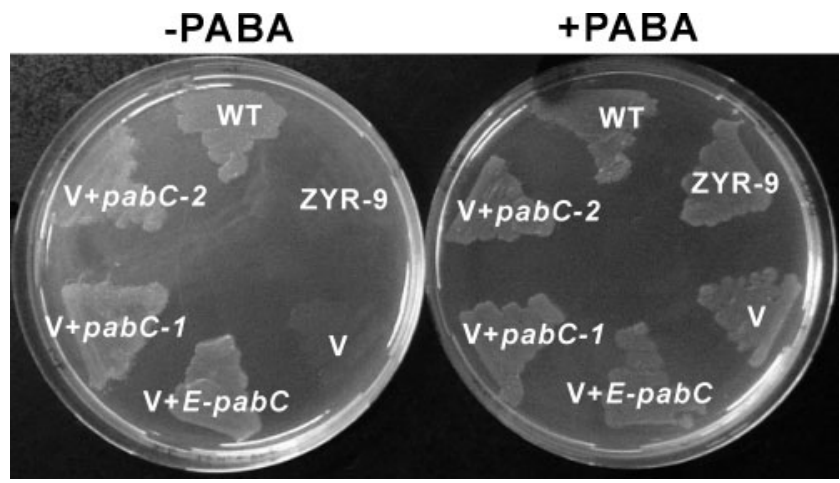

Fig. 5. Complementation of an $E$. coli pabC mutant with pabC-1 or pabC-2. Cells of wild-type (WT) E. coli, pabC mutant ZYR-9 (ZYR-9), ZYR-9 transformed with vector pET28a alone (V), ZYR-9 with cloned $E$. coli pabC $(\mathrm{V}+E-p a b C)$, ZYR-9 with cloned pabC$1(\mathrm{~V}+$ pabC-1), and ZYR-9 with cloned pabC-2 $(\mathrm{V}+$ pabC-2) were cultivated on $\mathrm{M} 9$ minimal medium supplemented or not with PABA. decrease in NADH occurred very slowly. When the substrate chorismate was omitted, the coupled reactions also occurred slowly. The slow decreases in each control may have been due to contamination with enzymes which can oxidize NADH to NAD (Fig. 6a). The assays of FR-008 PabC- 1 and PabC-2 proceeded in the same manner as that for E. coli PabC. When chorismate, PabB, and PabC-1 or PabC-2 were added, the $A_{340}$ dropped quickly, whereas a slow decrease in $A_{340}$ was observed in the absence of PabB, chorismate, PabC-1 (Fig. 6b) or PabC-2 (Fig. 6c). These results indicated that PabC-1 and PabC-2 need ADC as substrate to generate pyruvate, suggesting that both enzymes have ADC lyase activity.

\section{DISCUSSION}

The involvement of fused $p a b A B$ in candicidin biosynthesis was confirmed through gene inactivation and feeding with exogenous PABA (Campelo \& Gil, 2002). The abolition of antibiotic production was nearly complete, suggesting that the deficiency of ADC or PABA could not be remedied via primary metabolism. Attempts to clone discrete ADC synthase genes from Streptomyces were made in S. lividans (Criado et al., 1993) and S. venezuelae (Chang et al., 2001), with successful complementation of an E. coli pabB mutant. In $S$. venezuelae (the chloramphenicol producer), besides the knockout of the ADC synthase gene $c m l B$ for chloramphenicol biosynthesis, the inactivation of a second set of ADC synthase genes, $p a b A / p a b B$, did not affect growth on minimal medium, which suggested that additional unidentified ADC synthase genes might be present in the genome (Chang et al., 2001).

However, no attempt to identify an ADC lyase gene from Streptomyces has been reported. To the best of our knowledge, the gene pabC-1 represents the first confirmed ADC lyase gene in actinomycetes; its inactivation resulted in an $80 \%$ decrease of antibiotic FR-008 productivity (Fig. 2c). A putative ADC lyase gene was identified in the novobiocin biosynthetic gene cluster from S. spheroides, but no relevant function has been found (Steffensky et al., 2000). In aureothin and neoaureothin biosynthesis, the missing but required ADC lyase activity is most likely provided by the corresponding protein for PABA biosynthesis from primary metabolism. This assumption was supported by the successful heterologous expression of the aureothin gene cluster in S. lividans ZX1 (He \& Hertweck, 2003). The result that the SCO1546 mutant of S. coelicolor required PABA for growth on minimal medium (unpublished data) encouraged us to search for equivalent genes in the Streptomyces sp. FR-008 genome. Indeed, a SCO1546 homologue, pabC-2, which shows $85 \%$ identity with SCO1546, was cloned from the Streptomyces sp. FR-008 genome.

Double mutation of $p a b C-1$ and $p a b C-2$ almost completely abolished antibiotic FR-008 production (Fig. 3c), demonstrating that the remaining $20 \%$ production of anti- 

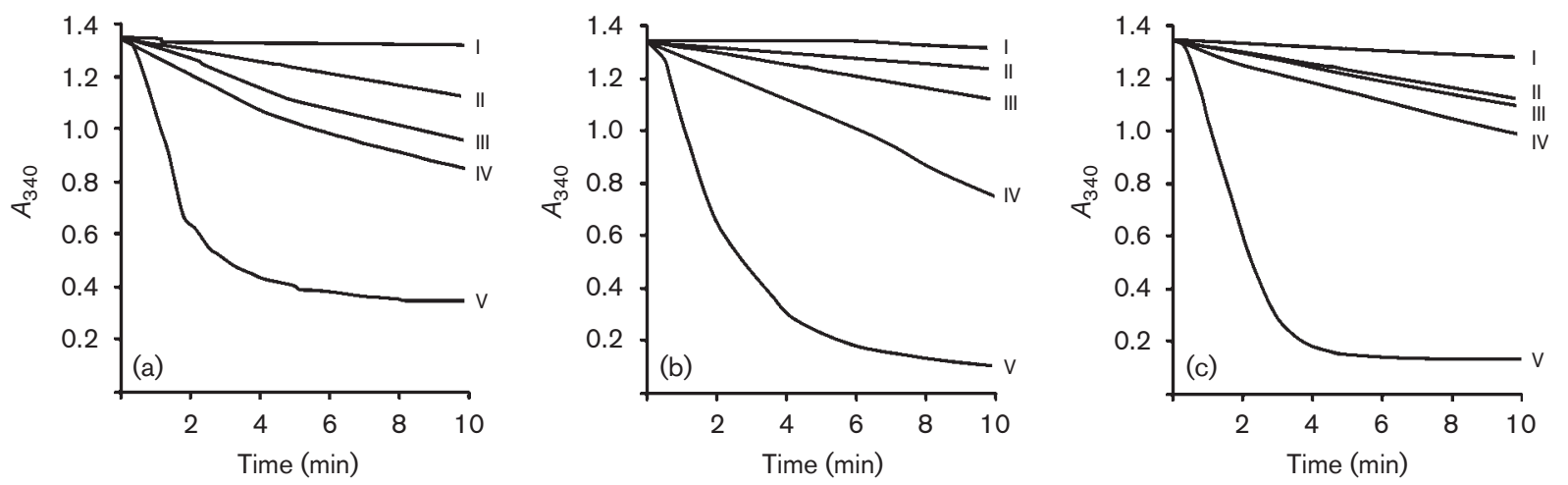

Fig. 6. Biochemical analysis of PabC (E. coli), PabC-1 and PabC-2. (a) PabC (E. coli): I, chorismate with boiled PabB and boiled PabC (E. coli); II, chorismate with PabB and boiled PabC (E. coli); III, chorismate with boiled PabB and PabC (E. coli); IV, $\mathrm{PabB}$ and PabC (E. coli), no chorismate; V, chorismate with PabB and PabC (E. coli). (b) PabC-1: I, chorismate with boiled PabB and boiled PabC-1; II, chorismate with PabB and boiled PabC-1; III, chorismate with boiled PabB and PabC-1; IV, PabB and PabC-1, no chorismate; V, chorismate with PabB and PabC-1. (c) PabC-2: I, chorismate with boiled PabB and boiled PabC-2; II, chorismate with PabB and boiled PabC-2; III, chorismate with boiled PabB and PabC-2; IV, PabB and PabC-2, no chorismate; $\mathrm{V}$, chorismate with $\mathrm{PabB}$ and $\mathrm{PabC}-1$. The recombinant $E$. coli $\mathrm{PabB}$ and $\mathrm{NH}_{4}^{+}$were used to convert chorismate to $A D C$, which is the substrate of ADC lyase. The pyruvate generated by ADC lyase was detected by an LDH-coupled assay, in which the decrease of $\mathrm{NADH}$ concentration was monitored continuously at $340 \mathrm{~nm}$; kinetic traces within 10 min are presented. The slow decrease in each control may be due to contamination with enzymes which can oxidize NADH to NAD.

biotic FR-008 in ZYR-6 was mostly contributed by the product of an ADC lyase gene outside the biosynthetic gene cluster. Moreover, the retarded growth of the pabC-1/ pabC-2 double mutant on minimal medium (Fig. 4) assigned $p a b C-1$ and $p a b C-2$ also to PABA synthesis in primary metabolism. Even though the double mutant showed retarded growth on minimal medium, noticeable growth still occurred. This may be caused by the slow spontaneous conversion from ADC to PABA (Tewari et al., 2002), low enzymic conversion by other ADC lyases in the mutant, or contamination by trace amounts of PABA in the medium.

Interestingly, PabC-2 shows high homology with its equivalent proteins from S. coelicolor (SCO1546, 81\% identity/89\% similarity), S. avermitilis (SAV6804, 80\% identity/90\% similarity) and S. griseus (SGR5991, 75\% identity $/ 85 \%$ similarity). Moreover, the three equivalent genes of $p a b C-2$ are all found to be sandwiched between an upstream putative anthranilate synthase gene and a downstream putative $\mathrm{N}$-acetyltransferase gene in each genome. The degenerate primers used for cloning of pabC-2 could also amplify specific PCR products of the expected size from some other Streptomyces studied in our lab (data not shown). This finding points to the probable common existence of pabC-2 equivalent genes in other Streptomyces.

In conclusion, two ADC lyase genes, including one ( $p a b C$ 1) from the antibiotic FR-008 biosynthetic gene cluster, have been functionally identified for the first time from actinomycetes. The interplay between these two genes in Streptomyces sp. FR-008, in both cell growth and antibiotic
FR-008 biosynthesis, sets a good example of a genetic coordination, rather than uni-directional flow, between primary and secondary metabolisms.

\section{ACKNOWLEDGEMENTS}

We thank Dr Shuangjun Lin for helpful discussions and critical reading of our manuscript. This work received financial support from the National Science Foundation of China, the Ministry of Science and Technology (973 and 863 Programs), the Ministry of Education (NCET Program), the Shanghai Municipal Council of Science and Technology, and Shanghai Leading Academic Discipline Project B203.

\section{REFERENCES}

Appling, D. R. (1991). Compartmentation of folate-mediated onecarbon metabolism in eukaryotes. FASEB J 5, 2645-2651.

Arhin, F. F. \& Vining, L. C. (1993). Organization of the genes encoding p-aminobenzoic acid synthetase from Streptomyces lividans 1326. Gene 126, 129-133.

Basset, G. J., Quinlivan, E. P., Ravanel, S., Rébeillé, F., Nichols, B. P., Shinozaki, K., Seki, M., Adams-Phillips, L. C., Giovannoni, J. J. \& other authors (2004). Folate synthesis in plants: the $p$-aminobenzoate branch is initiated by a bifunctional PabA-PabB protein that is targeted to plastids. Proc Natl Acad Sci U S A 101, 1496-1501.

Bentley, S. D., Chater, K. F., Cerdeno-Tarraga, A. M., Challis, G. L., Thomson, N. R., James, K. D., Harris, D. E., Quail, M. A., Kieser, H. \& other authors (2002). Complete genome sequence of the model actinomycete Streptomyces coelicolor A3(2). Nature 417, 141-147.

Bierman, M., Logan, R., O’Brien, K., Seno, E. T., Rao, R. N. \& Schoner, B. E. (1992). Plasmid cloning vectors for the conjugal transfer of DNA from Escherichia coli to Streptomyces spp. Gene 116, 43-49. 
Blanc, V., Gil, P., Bamas-Jacques, N., Lorenzon, S., Zagorec, M., Schleuniger, J., Bisch, D., Blanche, F., Debussche, L. \& other authors (1997). Identification and analysis of genes from Streptomyces pristinaespiralis encoding enzymes involved in the biosynthesis of the 4-dimethylamino-L-phenylalanine precursor of pristinamycin I. Mol Microbiol 23, 191-202.

Brown, M. P., Aidoo, K. A. \& Vining, L. C. (1996). A role for $p a b A B$, a p-aminobenzoate synthase gene of Streptomyces venezuelae ISP5230, in chloramphenicol biosynthesis. Microbiology 142, 1345-1355.

Campelo, A. B. \& Gil, J. A. (2002). The candicidin gene cluster from Streptomyces griseus IMRU 3570. Microbiology 148, 51-59.

Chang, Z., Sun, Y., He, J. \& Vining, L. C. (2001). p-Aminobenzoic acid and chloramphenicol biosynthesis in Streptomyces venezuelae: gene sets for a key enzyme, 4-amino-4-deoxychorismate synthase. Microbiology 147, 2113-2126.

Chen, S., Huang, X., Zhou, X., Bai, L., He, J., Jeong, K. J., Lee, S. Y. \& Deng, Z. (2003). Organizational and mutational analysis of a complete FR-008/candicidin gene cluster encoding a structurally related polyene complex. Chem Biol 10, 1065-1076.

Criado, L. M., Martin, J. F. \& Gil, J. A. (1993). The pab gene of Streptomyces griseus, encoding $p$-aminobenzoic acid synthase, is located between genes possibly involved in candicidin biosynthesis. Gene 126, 135-139.

Edman, J. C., Goldstein, A. L. \& Erbe, J. G. (1993). Paraaminobenzoate synthase gene of Saccharomyces cerevisiae encodes a bifunctional enzyme. Yeast 9, 669-675.

Gil, J. A. \& Hopwood, D. A. (1983). Cloning and expression of a $p$ aminobenzoic acid synthetase gene of the candicidin-producing Streptomyces griseus. Gene 25, 119-132.

Gil, J. A., Liras, P., Naharro, G., Villanueva, J. R. \& Martin, J. F. (1980). Regulation by aromatic amino acids of the biosynthesis of candicidin by Streptomyces griseus. J Gen Microbiol 118, 189-195.

Goncharoff, P. \& Nichols, B. P. (1984). Nucleotide sequence of Escherichia coli pabB indicates a common evolutionary origin of $p$ aminobenzoate synthetase and anthranilate synthetase. J Bacteriol 159, $57-62$.

Green, J. M. \& Nichols, B. P. (1991). p-Aminobenzoate biosynthesis in Escherichia coli. Purification of aminodeoxychorismate lyase and cloning of pabC. J Biol Chem 266, 12971-12975.

Gust, B., Challis, G. L., Fowler, K., Kieser, T. \& Chater, K. F. (2003). PCR-targeted Streptomyces gene replacement identifies a protein domain needed for biosynthesis of the sesquiterpene soil odor geosmin. Proc Natl Acad Sci U S A 100, 1541-1546.

He, J. \& Hertweck, C. (2003). Iteration as programmed event during polyketide assembly; molecular analysis of the aureothin biosynthesis gene cluster. Chem Biol 10, 1225-1232.

He, J., Magarvey, N., Piraee, M. \& Vining, L. C. (2001). The gene cluster for chloramphenicol biosynthesis in Streptomyces venezuelae ISP5230 includes novel shikimate pathway homologues and a monomodular non-ribosomal peptide synthetase gene. Microbiology 147, 2817-2829.

He, Z., Stigers Lavoie, K. D., Bartlett, P. A. \& Toney, M. D. (2004). Conservation of mechanism in three chorismate-utilizing enzymes. J Am Chem Soc 126, 2378-2385.

Hu, Z., Bao, K., Zhou, X., Zhou, O., Hopwood, D. A., Kieser, T. \& Deng, Z. (1994). Repeated polyketide synthase modules involved in the biosynthesis of a heptaene macrolide by Streptomyces sp. FR-008. Mol Microbiol 14, 163-172.

Kieser, T., Bibb, M. J., Buttner, M. J., Chater, K. F. \& Hopwood, D. A. (2000). Practical Streptomyces Genetics. Norwich, UK: John Innes Foundation.

Minagawa, K., Zhang, Y., Ito, T., Bai, L., Deng, Z. \& Mahmud, T. (2007). ValC, a new type of C7-cyclitol kinase involved in the biosynthesis of the antifungal agent validamycin A. ChemBioChem $\mathbf{8}$, 632-641.

Nichols, B. P., Seibold, A. M. \& Doktor, S. Z. (1989). Paraaminobenzoate synthesis from chorismate occurs in two steps. J Biol Chem 264, 8597-8601.

Ohnishi, Y., Ishikawa, J., Hara, H., Suzuki, H., Ikenoya, M., Ikeda, H., Yamashita, A., Hattori, M. \& Horinouchi, S. (2008). Genome sequence of the streptomycin-producing microorganism Streptomyces griseus IFO 13350. J Bacteriol 190, 4050-4060.

Omura, S., Ikeda, H., Ishikawa, J., Hanamoto, A., Takahashi, C., Shinose, M., Takahashi, Y., Horikawa, H., Nakazawa, H. \& other authors (2001). Genome sequence of an industrial microorganism Streptomyces avermitilis: deducing the ability of producing secondary metabolites. Proc Natl Acad Sci U S A 98, 12215-12220.

Paget, M. S., Chamberlin, L., Atrih, A., Foster, S. J. \& Buttner, M. J. (1999). Evidence that the extracytoplasmic function sigma factor $\sigma^{\mathrm{E}}$ is required for normal cell wall structure in Streptomyces coelicolor A3(2). J Bacteriol 181, 204-211.

Porat, I., Sieprawska-Lupa, M., Teng, Q., Bohanon, F. J., White, R. H. \& Whitman, W. B. (2006). Biochemical and genetic characterization of an early step in a novel pathway for the biosynthesis of aromatic amino acids and $p$-aminobenzoic acid in the archaeon Methanococcus maripaludis. Mol Microbiol 62, 1117-1131.

Sambrook, J., Fritsch, E. F. \& Maniatis, T. (1989). Molecular Cloning: a Laboratory Manual, 2nd edn. Cold Spring Harbor, NY: Cold Spring Harbor Laboratory.

Smokvina, T., Mazodier, P., Boccard, F., Thompson, C. J. \& Guerineau, M. (1990). Construction of a series of pSAM2-based integrative vectors for use in actinomycetes. Gene 94, 53-59.

Steffensky, M., Muhlenweg, A., Wang, Z. X., Li, S. M. \& Heide, L. (2000). Identification of the novobiocin biosynthetic gene cluster of Streptomyces spheroides NCIB 11891. Antimicrob Agents Chemother 44, 1214-1222.

Tewari, Y. B., Jensen, P. Y., Kishore, N., Mayhew, M. P., Parsons, J. F., Eisenstein, E. \& Goldberg, R. N. (2002). Thermodynamics of reactions catalyzed by PABA synthase. Biophys Chem 96, 33-51.

Traitcheva, N., Jenke-Kodama, H., He, J., Dittmann, E. \& Hertweck, C. (2007). Non-colinear polyketide biosynthesis in the aureothin and neoaureothin pathways: an evolutionary perspective. ChemBioChem $\mathbf{8}$, 1841-1849.

Triglia, T. \& Cowman, A. F. (1999). Plasmodium falciparum: a homologue of $p$-aminobenzoic acid synthetase. Exp Parasitol 92, 154158.

Ye, Q. Z., Liu, J. \& Walsh, C. T. (1990). p-Aminobenzoate synthesis in Escherichia coli: purification and characterization of $\mathrm{PabB}$ as aminodeoxychorismate synthase and enzyme $\mathrm{X}$ as aminodeoxychorismate lyase. Proc Natl Acad Sci U S A 87, 9391-9395.

Edited by: L. Heide 